\title{
Organisations and the production of migration and in/exclusion
}

\author{
Christine Lang ${ }^{1 *}\left(\mathbb{D}\right.$, Andreas Pott $^{1}$ and Kyoko Shinozaki ${ }^{2}$
}

\section{${ }^{*}$ Correspondence:}

christine.lang@uos.de

${ }^{1}$ University of Osnabrueck,

Osnabrück, Germany

Full list of author information

is available at the end of the

article

\begin{abstract}
The introductory article of this Special Issue explores the potential of an organisational perspective in comparative migration studies and for migration studies more broadly. Although organisations shape migration processes and the in/exclusion of migrants and their descendants in multiple ways, their role has long received surprisingly little attention in migration studies. Taking stock of the research engaging with organisations, we outline the main contours of the literature and suggest several conceptual perspectives that migration scholarship may benefit from. Based on the contributions included in this Special Issue, which focus on different types of organisations in diverse empirical contexts, we discuss three main patterns of organisational practices influencing migration and migrants' trajectories. These pertain to (1) decision-making about in/ exclusion and underlying categorisations, (2) the (re-)production of 'migrant figures', and (3) rationalities and structures shaping organisational practices.
\end{abstract}

Keywords: Organisations, Migration, Inclusion, Exclusion, Integration, Meso-level

\section{Introduction: the relative neglect of organisations in migration research}

Migration and the inclusion of migrants and immigrant descendants are fundamentally shaped by a multitude of organisations. ${ }^{1}$ Public administrations, for example, implement state laws and regulations, and decide upon the access to legal status and public services or the exclusion from these. While international organisations and border agencies monitor, control, or try to prevent cross-border mobility, schools, universities or companies attract, recruit, or discriminate against students and (potential) staff and thereby influence internal and international mobility as well as educational and professional careers. Organisations both enable and constrain spatial and social mobility, societal participation and life chances of migrants and their descendants. Thus, they are one of the key forces in producing migration movements, migrants' inclusion, and social change pertinent to migration.

However, surprisingly, the role of organisations has long received relatively little attention in migration studies as scholars have repeatedly noted (Bommes, 2003; Bührmann

\footnotetext{
${ }^{1}$ Sharing the critiques of the concept of 'integration' in migration research (Favell, 2010, 2019; Schinkel, 2018), we prefer using the term 'inclusion, inspired by systems theory perspectives, to conceive how individuals are addressed, involved or treated by different social systems (e.g. education, economy, politics) in specific ways (Bommes, 2012a). This highlights that individuals are never completely 'integrated' into society, as implicitly assumed when referring to the final stage of the 'integration' of migrants, but participate in distinct social systems, or societal contexts, in different ways. The same holds true for 'exclusion'. This perspective draws attention to the contextual conditions shaping in/exclusion.
}

(c) The Author(s), 2021. Open Access This article is licensed under a Creative Commons Attribution 4.0 International License, which permits use, sharing, adaptation, distribution and reproduction in any medium or format, as long as you give appropriate credit to the original author(s) and the source, provide a link to the Creative Commons licence, and indicate if changes were made. The images or other third party material in this article are included in the article's Creative Commons licence, unless indicated otherwise in a credit line to the material. If material is not included in the article's Creative Commons licence and your intended use is not permitted by statutory regulation or exceeds the permitted use, you will need to obtain permission directly from the copyright holder. To view a copy of this licence, visit http:// creativecommons.org/licenses/by/4.0/. 
\& Schönwälder, 2017; Castles et al., 2013; Pries, 2008, 2010). Empirical studies and conceptual debates have mainly concentrated on the macro and micro levels when seeking explanatory factors for international movements of people (Faist, 2010) and for migrants' inclusion and engagement in their new and old homes: on the one hand, a large body of research focuses on migration and integration policies, institutional arrangements or economic structures; on the other hand, there has been long-standing scholarly interest in individual migrants, migrant families and migrant groups. Whilst meso-level approaches focusing on social networks have become popular since around the 1990s (Boyd, 1989; Castells, 1996), they mainly look at interpersonal ties between individual migrants, or families and households, and less at organisations (Bilecen \& Faist, 2015; Faist, 2010). Notable exceptions are migrant, ethnic and hometown organisations, which have been a core topic in migration research (Caglar, 2006; Lamba-Nieves, 2018; Schrover \& Vermeulen, 2005).

Organisations as particular social formations are the object of a vast body of interdisciplinary scholarship developed since the early twentieth century mainly in sociology, political and administrative science and management studies but also in anthropology and psychology (for overviews see e.g. Bonazzi, 2014; Hatch, 2018; Scott \& Davis, 2007). Across the variety of theoretical approaches and definitions of 'organisations', we can note some main features that distinguish organisations from other meso-level entities such as social networks: Organisations formulate and communicate specific goals; they have members as defined according to their respective rules, which are a way of drawing the boundaries of an organisation; and they have formal and informal structures guiding their members' behaviour and decision-making. Examples of these structures are formalized programmes, rules, procedures, hierarchies, divisions of labour, and informal norms, expectations, and modes of thinking and doing. ${ }^{2}$

While organisations are often also referred to as 'institutions', especially public organisations, organisational scholars would highlight the difference. With neo-institutional approaches, institutions may be defined as "regulative, normative and cultural-cognitive elements that, together with associated activities and resources, provide stability and meaning to social life" (Scott, 2008, p. 48). Organisations are crucially shaped by institutions and incorporate institutional features in their structures, but they can be differentiated and examined as specific social formations.

This broad conception of organisations encompasses state bureaucracies, ${ }^{3}$ schools, faith-based organisations, or the army, alongside companies, NGOs and voluntary associations as well as 'criminal organisations' such as the Mafia or human traffickers. Yet, despite this diversity, organisations have to deal with similar problems. For instance, they must secure resources, members, and legitimacy for their survival, and develop appropriate structures to pursue their goals, manage their actions and cope with uncertainty. Organisational research shows that there are specific processes, mechanisms,

\footnotetext{
${ }^{2}$ A widespread typology distinguishes three conceptions of organisations that have developed over time-rational, natural, and open systems-which emphasize different features (Scott \& Davis, 2007). An attempt at an overarching definition describes organisations as "goal-directed, boundary-maintaining, and socially constructed systems of human activity" (Aldrich, 1999, p. 2).

${ }^{3}$ From an organisational theory perspective, the state itself would not be considered as a single organisation but as being composed of different organisations (e.g. administrations, ministries, parliaments).
} 
rationalities, modes of behaviour and decision-making that characterize the activities in and of organisations.

In migration studies, the particularities of organisations have been little considered as factors shaping the conditions of migration and migrants' in/exclusion. Organisations are often conceived as part of the state apparatus or subsumed under the respective structural and institutional context. As such, they appear as expressions or 'executors' of other forces, or simply remain unspecified, rather than being seen as specific social systems that produce effects which are not directly derived from state regulations or structural conditions (Rodriguez, 2010).

It is hard to pinpoint what has contributed to the relative neglect of organisations, in particular of non-migrant organisations, in migration studies. Partly, it may have to do with the scholarly preoccupation with migrants at the expense of closely analysing the societal production of 'migrants' and 'migration', which has been criticised as the "migration container" of migration research (Dahinden, 2016, p. 2208). The tendency of empirical migration studies to 'decouple' migrants, their pathways, and families from larger, not 'migration-specific' social structures hampers engagement with general social theories.

For some years, however, we have been witnessing a growing research interest in different types of organisations involved in processes of migration and migrants' in/exclusion. This Special Issue aims to foster these engagements by showing how the study of migration may benefit from a more explicit focus on the role of organisations. We bring together contributions investigating different types of organisations in selected contexts, which reveal particular ways in which these organisations shape migration and inclusion. Our deliberate selection of a range of empirical contexts allows comparing the role of organisations across settings and subfields of migration research, thus shedding light on overarching organisational practices, structures, and rationalities. We believe that the focus on organisations may reveal new avenues for innovative comparative migration research and that it may advance theories.

In what follows, we begin by briefly surveying the pertinent literature, taking stock of the research on organisations in migration studies. Our aim here is not to provide an exhaustive literature review, but to show main areas of research engaging with organisations and existing gaps. We will then sketch out what organisational perspectives in migration studies might mean. The fourth section introduces the contributions of the Special Issue along with three main aspects of the role of organisations they shed light on.

\section{Migration studies and organisations}

Emphasising the need for more systematic consideration of organisations in migration studies does not mean ignoring already existing research on organisations. Especially in recent years, a growing number of studies have examined the relevance of different organisations for processes of migration and in/exclusion. Yet this research has so far remained largely compartmentalised, impeding comparative perspectives across fields of research and cross-fertilisation of knowledge. Our overview first points to literature on migrants' self-organising, as the most prominent engagement of migration scholars with organisations so far, to then look at several further strands of literature focusing 
on organisations in processes of migration and of migrants' in/exclusion in receiving contexts.

Migrant and ethnic organisations are undoubtedly the most well-studied type of organisations. Scholars have examined their formation in receiving contexts (e.g. Vermeulen, 2006; classic: Breton, 1964), their role in social and political inclusion (Fauser, 2012; Pilati \& Morales, 2016; Pries, 2010; Tillie, 2004) and minority politics (Caponio, 2005; Ireland, 1994; Nicholls \& Uitermark, 2013; Però, 2008). Transnational studies have shown the importance of migrant and hometown organisations for both maintaining and nurturing old ties and creating new relations between places of destination and origin (Pries, 2008; Pries \& Sezgin, 2012). Through transnationally active organisations, 'old' homeland-bound relations continue to be mediated in various societal contexts (Halm \& Sezgin, 2013), such as religion (Levitt, 2004) and politics (Østergaard-Nielsen, 2003; Portes et al., 2008). While not all research on migrant organisations takes the organisations themselves as an object of inquiry, a number of studies provide useful insights into organisational characteristics and logics underlying their formation and activities (Gnes, 2016; Rosenow-Williams, 2014; Sezgin, 2010; Vermeulen, 2006).

In research on migration processes, the past decade has seen an increasing interest in the "migration industry", a set of often profit-oriented actors facilitating and channelling spatial mobility (Cranston et al., 2018; Gammeltoft-Hansen \& Sorensen, 2013; Lindquist et al., 2012). Scholars look at commercial agencies and state organisations, as well as their interlinkages, establishing migration corridors and brokering workers in different sectors of the labour market, for example, domestic workers (Debonneville, 2021, in this issue; Lindquist et al., 2012), care professionals (Walton-Roberts, 2021), IT workers (Xiang, 2007), expatriates, NGO workers and professionals in cultural organisations (Adick et al., 2014). The migration industry literature also engages with the production of international student mobility (Beech, 2018; Liu-Farrer \& Tran, 2019) and with the "business" of trafficking organisations (Salt \& Stein, 1997). Studies show that independent of migrant skill levels, the aspect of "creating" and "marketing" the respective migrant figures plays a crucial role (Findlay et al., 2013; Rodriguez, 2010).

Another growing subfield of study pays attention to state and non-state actors involved in governing and controlling migration. The role of international organisations in the "management" of migration (Geiger \& Pécoud, 2014) is a case in point, as several studies illustrate focusing on IOM (Andrijasevic \& Walters, 2010; Georgi, 2010; Pécoud, 2018) and UNHCR (Hantscher, 2019; Scheel \& Ratfisch, 2014). These organisations actively participate in framing, conceptualizing and problematising migration movements. By doing so, international organisations produce specific kinds of representation of migration and migrants. Research on border agencies controlling or trying to prevent crossborder movements shows that their practices are far from following coherent strategies as presented by their official mandates but are characterised by tensions between different rationalities (Achermann, 2021, in this issue; Perkowski, 2019). Tensions also appear in the activities of NGOs involved in "migration management", for example by search and rescue operations, which have to deal with contradictions between their humanitarian and political goals (Cuttitta, 2018).

In receiving contexts, organisations continue to regulate migration, settling processes and in/exclusion. This is illustrated by the burgeoning field of research on public 
administrations treating asylum applications and stay permits. Studies reveal bureaucrats' everyday practices, decision-making and scope for discretion (Dahlvik, 2018; Eule, 2016; Scheffer, 2001; Triandafyllidou, 2003) or demonstrate different logics of vulnerability they deploy to legitimise an existing legal framework (Reitter, forthcoming). State administrations do not simply execute legal rules and policy directives but negotiate and shape their meaning in practice (Affolter, 2021, in this issue) and actively provide (or do not provide) migrants and asylum seekers with access to territories and legal status. Also, the administrative implementation of immigration and asylum policies is not linear but may be accompanied by tensions and distortions (Boswell, 2015).

Similarly, scholars investigating the local governance of migration and migrationrelated diversity have been interested in public administrations implementing policies that target the immigrant population. Studies emphasise discrepancies between an official rhetoric of 'integration' or 'diversity' and administrative practice (Bommes, 2012b; Schiller, 2016) and point to the role of organisational structures and decision-making rationalities in shaping whether and how policy is put into practice (Lang, 2020).

Further research on the in/exclusion of migrants and their descendants in receiving contexts has paid attention to the role of organisations in enabling/constraining access to labour markets. Studies have investigated how employers discriminate against applicants of migrant descent in recruitment decisions and routines (Imdorf, 2010; Lang, 2021, in this issue; Meziani-Remichi \& Maussen, 2017; Midtbøen, 2014; Waldinger \& Lichter, 2003). Comparative research has pointed out that organisational factors such as internal policies, procedures, or notions of 'suitability' and 'skill' account for crossorganisational variance in immigrant employment (Elrick, 2016; Lang, 2019). Organisations may also actively promote immigrant employment as recent research on labour market intermediaries illustrates (Maletzky de García, 2021, in this issue).

Yet another growing body of literature focuses on the accommodation of migrationrelated religious diversity, specifically of Muslim religious practices, in various settings. Looking at private and public employers (Adam \& Rea, 2018), schools and hospitals (Bertossi \& Bowen, 2014), prisons (Harms-Dalibon, 2017) or the army (Bertossi, 2014; Michalowski, 2015), these studies shed light on the complexity of negotiation processes and logics affecting modes of inclusion.

Given that the issue of educational inequalities has been a key topic in migration studies, a relative lack of organisational takes in this field is surprising. However, some studies show the role of school segregation for educational achievements (Sykes \& Kuyper, 2013) and institutional discrimination, racism and 'whiteness' in schools (Gomolla \& Radtke, 2009; Karakayali \& zur Nieden, 2013; Weiner, 2015) and higher education institutions (Ahmed, 2012; Gutiérrez-Rodríguez, 2016; Osanami Törngren \& Shinozaki, 2021; Thompson \& Zablotsky, 2016), which provides (still rare) insights into organisational structures and routines (re-)producing disadvantages and exclusion.

Based on this brief, admittedly selective, overview, we want to emphasise three aspects. Firstly, while migration scholars in fact increasingly look at organisations, they do not necessarily investigate organisations as specific social systems characterised by distinctive logics of action that have a structuring effect on phenomena of migration and in/exclusion of migrants and their descendants. As a result, the organisational mechanisms continue to remain rather vague. Secondly, the current body of literature still lacks 
comparative takes on organisations. Most empirical studies concentrate on a specific type of organisation and setting and hardly engage with research on other organisations and societal contexts. ${ }^{4}$ This obstructs seeing potential similarities in the role of organisations across the phenomena studied, leading to fragmentation of knowledge to date. Thirdly, apart from a few important exceptions (e.g. Debonneville, 2021, in this issue; Leung, Waters, \& Ki, forthcoming, in this issue; Lindquist et al., 2012; Liu-Farrer \& Tran, 2019; Xiang, 2007), the research mainly pays attention to contexts in the Global North, in particular Western Europe, which limits our view on the role of organisations. Some of our contributions look at Asian contexts, contributing to correcting the Western bias.

\section{Using organisational perspectives in migration studies}

To better understand the 'organised' character of many of the processes shaping migration movements and migrants' inclusion in, or exclusion from, different societal contexts, migration scholarship may benefit from using organisational perspectives. This means, in a methodological sense, taking organisations as units of analysis. While qualitative approaches may reveal patterns of organisational practices and processes, and the structures, mechanisms and rationalities shaping these, quantitative approaches may allow measuring the impact of different organisational-level factors on organisational practices and their effects on migrants' trajectories and in/exclusion.

Furthermore, empirical analyses may benefit from theoretical approaches that help to grasp the functioning of organisations, i.e. how organisations and their members act and why they act the way they do. The potential of such approaches has already been underlined for the study of migrant organisations (Halm \& Sezgin, 2013; Pries, 2010). Building on this, we argue that organisational theory provides useful analytical perspectives enhancing our understanding of the role of the organisational meso-level for migration and in/exclusion more generally. Particularly in organisational sociology, we find a large set of approaches and concepts, which draw on multiple theoretical traditions, including the behavioural theory of decision-making (March \& Simon, 1993), neo-institutionalism (Scott, 2008), and systems theory (Luhmann, 2018). Also, more general social theories such as actor-network theory (Czarniawska \& Hernes, 2005) and Bourdieu's practice theory (Emirbayer \& Johnson, 2008) have been applied to organisations. Moreover, a broad spectrum of middle-range concepts has been offered by other disciplines. Drawing on different organisational approaches and existing studies in migration research, we would like to suggest three analytical perspectives useful for migration studies.

First this is a focus on the modes and processes of organisational decision-making: Organisational scholars following the behavioural theory of decision-making have long argued that organisational decisions are far from being the product of 'rational choices' or linear processes. They are rather made in a context of "bounded rationality" and "ambiguity" (March, 1990; March \& Simon, 1993) and under circumstances of "organized anarchies" (Cohen et al., 1972, p. 1) characterized by inconsistent preferences, trialand-error-like procedures and fluctuating participants. Decision-making is compared with a "garbage can" (Cohen et al., 1972, p. 2) in which problems, solutions, participants,

\footnotetext{
${ }^{4}$ A notable exception are recent developments in the abovementioned research on the "migration industry" that take an overarching look at the forms and functioning of "migration industries" in different contexts (Cranston et al., 2018).
} 
and decision-making opportunities are dumped and rather coincidentally mixed. While this draws attention to the complex, contingent and conflictual interplay of different elements producing organisational practices and decisions, such as actors, interests, perceptions of problems, strategies, rationalities, settings etc., constructivist approaches emphasize the importance of "sensemaking" processes in organisations to reduce ambiguity and establish the degree of certainty needed for an organisation to function (Weick, 1995). Specific modes of behaviour and practices have also been described for particular types of organisations. An example is the "street-level bureaucracy" approach (Lipsky, 1980), which depicts decision-making at the frontline of organisations delivering public services (e.g. public administrations, the police, schools, hospitals). Highlighting the inherent discretion and autonomy of public service workers implementing policies and deciding upon the allocation of public goods and sanctions, this approach points out that their actions are not neutrally executing rules and policies but crucially shaping their practical significance.

For migration scholars, a more in-depth investigation of decision- and sensemaking processes in organisations, taking inspiration from these or other theoretical accounts, will allow a better understanding of the organisational practices impacting on migrants' trajectories and in/exclusion. These include the practices of border agencies deciding on access to a territory (Achermann, 2021, in this issue), public administrations distributing legal status (Affolter, 2021, in this issue; Dahlvik, 2018), public clinics offering healthcare (Perna, 2021, in this issue), employers recruiting for jobs (Bommes, 2012c; Imdorf, 2010; Lang, 2021, in this issue), and schools selecting and teaching immigrant or internationally mobile students (Gomolla \& Radtke, 2009; Leung, Waters, \& Ki, forthcoming, in this issue).

Second, also warranting closer attention are the internal structures shaping the behaviour, practices and decision-making processes in and of organisations. Organisational structures, which include formal and informal aspects, have for instance been defined as composed of three elements (Luhmann, 2018): 'programmes' defining the conditions and goals for action, such as rules and plans but also well-established routines; 'communication channels', such as officially or informally-developed hierarchies, divisions of tasks and power positions; and the 'personnel' with its professional knowledge as well as its personal characters, motivations, and networks. ${ }^{5}$ Organisational structures might also take international and transnational forms (Pries, 2008). Further, organisations are characterised by specific cultures (e.g. Martin, 2001) - namely, institutionalised values, rituals and 'ways of doing' which may also be understood as "habitus" (Affolter, 2021, in this issue) - and specific identities or self-descriptions (Albert \& Whetten, 1985; Luhmann, 2018). These may also influence the behaviour and practices of an organisation and its members.

Focusing on organisational structures can, for example, shed light on the hierarchies, procedures, routines, and cultures (re-)producing racial inequalities within organisations (Acker, 2006; Ahmed, 2012; Ray, 2019; Wooten, 2019) or impacting on practices which affect migrants and individuals of immigrant origin as clients and

${ }^{5}$ Other definitions of organisational structures distinguish, e.g. complexity, formalization, and centralization (Tolbert \& Hall, 2009). 
addresses of organisations (Affolter, 2021, in this issue; Gomolla \& Radtke, 2009). Moreover, structural analysis helps to provide explanations for cross-organisational variance of practices shaping migrant trajectories and in/exclusion. This is particularly relevant for comparative research (Elrick, 2016; Lang, 2021, in this issue; Perna, 2021, in this issue).

Third, analyses can focus on the relations between organisations and their environment: Organisational practices are shaped by and respond to their societal environment and need to reconcile different external and internal expectations. This has been particularly theorized by the neo-institutional approach, which argues that organisations must secure societal legitimacy to gain resources and ensure survival (Deephouse \& Suchman, 2008). Thus, they must demonstrate that their structures and actions conform to legal rules, societal norms and widespread cultural beliefs. Yet the adaptation to institutional environments may only be symbolic and ceremonial, whilst the practices continue unchanged: "Decoupling" is identified as a common strategy to respond to environmental expectations that contradict internal demands (Meyer \& Rowan, 1977), and to an institutional environment that is complex and inconsistent (Brunsson, 2006). Further strategies may range from acquiescence to manipulation of institutional environments (Oliver, 1991).

Migration scholars have already fruitfully applied neo-institutional approaches in research to a large spectrum of topics such as the practices of border agencies (Perkowski, 2019) and labour market intermediaries (Maletzky de García, 2021, in this issue), the use of expert knowledge on migration by state administrations (Boswell, 2009), the implementation of policies aiming to improve irregular migrants' access to healthcare (Perna, 2021, in this issue) and workforce diversity (Lang, 2020), as well as the formation, practices and transformation of migrant organisations (Gnes, 2016; Rosenow-Williams, 2014; Sezgin, 2010; Vermeulen \& Brünger, 2014).

An important part of the environment of organisations is other organisations. The concept of the "organisational field" coined by neo-institutionalist theory (Wooten \& Hoffman, 2017), draws attention to interorganisational relations and how they shape organisational structures and processes. Organisational fields can be broadly defined as including all organisations "meaningfully involved in some collective enterprise-whether producing a product or service, carrying out some specific policy, or attempting to resolve a common issue" (Scott, 2008, p. 208) and who, in doing so, operate within a shared institutional framework. Organisational fields have been debated regarding their homogenizing effects on organisations by coercive, mimetic and normative mechanisms (DiMaggio \& Powell, 1983). Under conditions of uncertainty, organisations tend to imitate other organisations in the field. Conversely, conflict-theoretical approaches emphasize the interorganisational power struggles (Emirbayer \& Johnson, 2008; Fligstein \& McAdam, 2012), linking the organisational field concept with a Bourdieusian conception of social fields (Bourdieu \& Wacquant, 1992).

In migration research, the analytical gain of an organisational field perspective has been sketched out for migrant organisations operating in complex environments and relations with diverse other organisations (Pries, 2010). Likewise, it might be fruitful for studying the interplay of actors in the migration industry (Acacio, 2011) or in 
politics and governance of migration and immigrant inclusion (Nicholls \& Uitermark, 2013; Ruszczyk, 2018).

By outlining the potential of organisational perspectives in migration research, we aim to stimulate ideas for future research agendas. Focusing on the organisational meso-level empirically and conceptually will reveal important processes, rationalities, mechanisms and structures shaping migration and the in/exclusion of migrants.

\section{The contributions}

The seven contributions included in this Special Issue present case studies of different types of organisations and empirical sites. They illustrate the pivotal role of organisations and their practices in multiple contexts, ranging from access to a state's territory, legal status, and healthcare to inclusion in education, employment and the (transnational) labour market as well as the related spatial and social mobility opportunities.

As outlined in the previous section, organisational approaches are by no means uniform. They are diverse in terms of theoretical premises (e.g. structural approach, or practice- and process-oriented approach), analytical focus (e.g. on the "street level", the overall organisation, or a [transnational] organisational field), and unit of reference (intra-organisational analysis vs. relationship with external environment), just to name a few. This heterogeneity is mirrored in the following contributions. While the authors draw on different theoretical lenses, they all look at organisations as distinct entities whose actions, or those of their members, follow specific organisational logics, illustrating the gains of the analytical perspectives outlined above. In brief, the authors all focus on the 'productivity' of organisations-how they produce migration and migrants' in/ exclusion in different societal contexts. This presents the main contribution of this Special Issue.

\section{Talking across organisations}

What do organisations do? How can we explain what the case studies observe? Across the different organisations and empirical contexts analysed by this Special Issue's contributions, we can identify three patterns of organisational practices that have an effect on migrants' trajectories.

First, the contributions show how organisations decide about in/exclusion in or from societal contexts and, in doing so, differentiate, categorise, and evaluate individuals. Christin Achermann reveals how the Swiss Border Guard differentiates 'un/authorised' border-crossers in producing decisions about whom to control at the border and to grant or refuse entry. Categorisations also play a role in the administrative practice in a Swiss Asylum Office, as Laura Affolter demonstrates, when administrators decide on the 'credibility' of applications. For access to healthcare in the North Italian region of Piemonte that Roberta Perna's work investigates, it is crucial for migrants with irregular status to fit the categories of 'deservingness' and 'neediness.' In terms of inclusion in the labour market and education, organisations continue to differentiate and evaluate individuals as part of their decision-making. In the context of personnel recruitment, Christine Lang analyses the ways in which Berlin public administration gauges the suitability of candidates, and how this affects the opportunities of young people of migrant descent to access employment. In their contribution on Chinese cross-border students commuting 
to schools in Hong Kong, Maggi Leung, Johanna Waters and Yutin Ki show how educational organisations coproduce mobility and difference. Here, mainland-Chineseness is (re-)produced not only through the language of instruction (English and Cantonese), but also through the (non-)adaption of school programmes to the needs of students who have to travel long spatial distances.

Other contributions reveal how categories are created by intermediary organisations which select migrants based on assumptions about their 'fit' to jobs. Taking programmes of labour market integration of refugees as an example, Martina Maletzky de García shows that German Professional Chambers distinguish refugees in terms of the types of capital they possess, or can possibly accumulate, when they select candidates for training and apprenticeship opportunities. In the case of the Philippines, one of the bestknown sending contexts, Julien Debonneville renders visible how recruitment agencies classify and filter job seekers looking for employment abroad as domestic workers along the lines of age, religion, marital status, and financial resources.

Second, the articles illustrate that by way of differentiating and categorising, organisations (re-)produce how migrants are commonly, or stereotypically, perceived. For example, irregular migrants seeking medical treatment are referred to by staff in public health organisations as being 'vulnerable,' 'patients', or 'medical tourists' (Perna). Both motivating and justifying practices of in/exclusion, these framings reinforce images of migrants as a marginalised social group, helped by 'us' (locals), or as 'illegal' exploiters taking advantage of the system. Stereotypical representations of 'migrant figures' are also central to the selection of candidates in a hiring process in public administrations (Lang), as well as to the matchmaking of domestic workers and employers by commercial agencies (Debonneville) and of refugees and employers by Professional Chambers (Maletzky de García). Mobilising such representations legitimises, for example, maintaining recruitment routines likely to exclude young people with migrant parents, whilst the very same representations ironically work to justify hiring decisions for candidates of immigrant origin (Lang). Here again, we can see that not only does the stereotyping further fixate the existing imaginaries associated with certain migrant groups, but that it also serves the organisations to reduce uncertainty and complexity and to legitimise their practices. Ensuring legitimacy is important to secure resources and organisational survival as neoinstitutionalists suggest (Deephouse \& Suchman, 2008). Philippine agencies would argue that employers can have a 'tailored' domestic worker placed who fulfils her/his specific needs because they claim to know what 'profile' is favoured by employers (Debonneville). Organisations not only (re-)produce stereotypical images of migrants but also of themselves to secure their survival for which they may rely on migrants as clients. This illustrates, for example, the case of Hong Kong schools nurturing the narrative of 'Hong Kong style education' to attract cross-border students (Leung, Waters $\mathcal{E}$ Ki).

Third, the authors in this issue reveal how different internal and external rationalities and structures shape organisations' practices addressing and in/excluding migrants or individuals of immigrant descent. Organisations respond to their environment in their respective fields, which often poses diverse and conflicting demands. Schools in Hong Kong mediate macro-level immigration policies imposed on mainland Chinese students who have to cross borders twice a day and micro-level everyday experiences (Leung, Waters $\&$ Ki). If this example speaks to the legal environment and familial aspirations 
for accessing 'better education', other contributions show how organisational practices address, combine, and translate different legal regulations and/or policies and public discourses through their practices. This includes expectations to contribute to the integration of migrants and immigrant descendants (Lang; Maletzky de García), to conform to the framing of protecting migrants (Debonneville), or to respect humanitarian and national security rationales in deciding over migrants' access to the territory, legal status and public goods (Achermann; Affolter; Perna). In addition, these partly inconsistent institutional expectations often have to be combined with economic and efficiency demands (see contributions by Achermann; Debonneville; Lang; Maletzky de García). In fact, economic logics and efficiency requirements underlie many of the organisational practices presented in these case studies, including those of state organisations. On the other hand, private agencies not only follow economic rationales; they also operate in an institutional context in which they are expected to comply with legal rules and policy frameworks. Indeed, having to negotiate and combine different institutional and resource requirements may be considered a specific characteristic of organisations. An organisational perspective thus highlights that macro-level structures such as laws and policies on migration or integration, or economic power relations, do not imprint themselves directly onto the process of migration and inclusion. Instead, they are mediated by the practices of organisations combining multiple rationalities.

The contributions looking at the 'street-level' and policy implementation in state organisations elucidate that organisations, and their members, make use of discretion as a leverage to find their way out of institutional contradictions and inconsistencies between organisational realities and legal/policy frameworks (see contributions by Achermann; Affolter; Lang; Leung, Waters \& Ki; Perna). Their handling resonates with what neo-institutionalists call "decoupling", that is, disconnecting official rhetoric and formal structures from actual practices (Brunsson, 2006; Meyer \& Rowan, 1977). The contributions confirm the view that organisations and their members are not merely neutral operators of policies and laws but effectively cocreate their meaning, which might get institutionalised in the long run. Such institutionalisation also takes shape within organisations: established routines and 'ways of thinking' form an "institutional habitus" (Affolter) which influences members' behaviour and thus the organisational decision-making.

\section{Conclusions}

The comparison across the various organisations studied in this Special Issue reveals common patterns of organisational practices shaping migration and migrants' in/ exclusion in different societal contexts. Yet these organisations obviously also differ in terms of how they make decisions, how they differentiate migrants or migrant descendants, and what logics they follow. Differences regarding the in- or exclusionary effects of practices may relate to internal organisational structures such as the orientation of the management, the allocation of resources and the programmes in place, as shown in the contributions which build on comparative case studies (see contributions by Lang and Perna). Furthermore, the official goals and self-descriptions of an organisation (e.g. securing borders, providing healthcare, educating students, matching workers and employers), its structure (e.g. its programmes, hierarchy, distribution of decision-making 
competences), the environment in which it is embedded, as well as the related expectations it has to deal with, all have an impact on its practices. As a result, they influence the way an organisation shapes migration and in/exclusion. Investigating the role of such organisational characteristics offers fruitful research avenues for comparative migration studies.

Considering the scant attention paid to organisations for a long time, much more extensive research is needed to systematically explore and compare different types of organisations and their role in a range of migration-related phenomena: We have only begun to grasp the enormous degree of influence organisations have on the spatial patterns of migration as well as the unequal distribution of chances for inclusion in the multiple social contexts of transit, arrival, origin, or return. Invigorating the study of organisations would enhance the possibility for developing more differentiated and nuanced typologies of 'migration-producing' organisations and organisational processes. This also requires deeper engagement in theoretical debates. Intensifying the slowly emerging exchange between organisation-related migration research and more general research on organisations would advance theory development. We are convinced that both fields of research can enrich each other.

Finally, strengthening organisational perspectives in all fields of migration research would contribute to the endeavour to de-essentialise and 'de-migranticise' research on migration and inclusion (Dahinden, 2016). Scrutinising organisations helps to shift our research focus away from migration and migrants as seemingly given and taken-forgranted objects of research. What it allows instead is a rigorous and stimulating analysis of the social production of migration.

\section{Acknowledgements}

The authors would like to thank the contributors to this special issue for their participation and Dženeta Karabegović as well as the two reviewers for their thorough reading and valuable feedback.

\section{Authors' contributions}

All authors contributed to this article and read and approved the final manuscript.

Funding

None.

Availability of data and materials

None.

\section{Declarations}

Competing interests

The authors declare that they have no competing interests.

Author details

${ }^{1}$ University of Osnabrueck, Osnabrück, Germany. ${ }^{2}$ Paris Lodron University of Salzburg, Salzburg, Austria.

Received: 2 July 2021 Accepted: 10 November 2021

Published online: 29 December 2021

\section{References}

Acacio, K. A. S. (2011). Getting nurses here: Migration industry and the business of connecting Philippine-Educated Nurses with United States Employers. Dissertation UC Berkeley. Retrieved from https://escholarship.org/uc/item/7rz1 k2sv

Acker, J. (2006). Inequality regimes: Gender, class, and race in organizations. Gender and Society, 20(4), 441-464.

Adam, I., \& Rea, A. (2018). The three "i"s of workplace accommodation of Muslim religious practices: Instrumental, internal, and informal. Ethnic and Racial Studies, 41(15), 2711-2730.

Adick, C., Maletzky, M., Pries, L., \& Gandlgruber, B. (2014). Cross-border staff mobility: A comparative study of profit and nonprofit organisations. Springer. 
Achermann, C. (2021). Shaping migration at the border: The entangled rationalities of border control practices. Comparative Migration Studies, 9(1), 5. https://doi.org/10.1186/s40878-020-00214-0

Affolter, L. (2021). Regular matters: Credibility determination and the institutional habitus in a Swiss asylum office. Comparative Migration Studies, 9(1), 4. https://doi.org/10.1186/s40878-020-00215-z

Ahmed, S. (2012). On being included: Racism and diversity in institutional life. Duke Univ. Press.

Albert, S., \& Whetten, D. A. (1985). Organizational identity. Research in Organizational Behavior, 7, 263-295.

Aldrich, H. (1999). Organizations evolving. SAGE Publications.

Andrijasevic, R., \& Walters, W. (2010). The International Organization for Migration and the International Government of Borders. Environment and Planning D: Society and Space, 28(6), 977-999.

Beech, S. E. (2018). Adapting to change in the higher education system: International student mobility as a migration industry. Journal of Ethnic and Migration Studies, 44(4), 610-625.

Bertossi, C. (2014). French "Muslim" soldiers? Social change and pragmatism in a military institution. In J. R. Bowen, C. Bertossi, J. W. Duyvendak, \& M. L. Krook (Eds.), European States and their Muslim citizens: The impact of institutions on perceptions and boundaries (pp. 73-103). Cambridge University Press.

Bertossi, C., \& Bowen, J. R. (2014). Practical schemas, conjunctures, and social locations. Laicité in French Schools and Hospitals. In J. R. Bowen, C. Bertossi, J. W. Duyvendak, \& M. L. Krook (Eds.), European States and their Muslim Citizens: The impact of institutions on perceptions and boundaries (pp. 104-131). Cambridge University Press.

Bilecen, B., \& Faist, T. (2015). International doctoral students as knowledge brokers: Reciprocity, trust and solidarity in transnational networks. Global Networks, 15(2), 217-235.

Bommes, M. (2003). Die politische "Verwaltung" von Migration in Gemeinden. In J. Oltmer (Ed.), Migration steuern und verwalten (pp. 459-480). V\&R Unipress.

Bommes, M. (2012a). Migration in modern society. In C. Boswell \& G. D'Amato (Eds.), Immigration and social systems: Collected essays of Michael Bommes (pp. 19-35). Amsterdam University Press.

Bommes, M. (2012b). "Integration takes place locally": On the restructuring of local integration policy. In C. Boswell \& G. D’Amato (Eds.), Immigration and social systems: Collected essays of Michael Bommes (pp. 125-155). Amsterdam University Press.

Bommes, M. (2012c). Systems theory and the "ethnic inequality" of migrant workers. In C. Boswell \& G. D’Amato (Eds.), Immigration and social systems: Collected essays of Michael Bommes (pp. 59-82). Amsterdam University Press.

Bonazzi, G. (2014). Geschichte des organisatorischen Denkens (2nd ed.). Springer.

Boswell, C. (2009). The political uses of expert knowledge: Immigration policy and social research. Cambridge University Press.

Boswell, C. (2015). The double life of targets in public policy: Disciplining and signalling in UK Asylum policy. Public Administration, 93(2), 490-505.

Bourdieu, P., \& Wacquant, L. J. D. (1992). An invitation to reflexive sociology. University of Chicago Press.

Boyd, M. (1989). Family and personal networks in international migration: Recent developments and new agendas. International Migration Review, 23(3), 638-670.

Breton, R. (1964). Institutional completeness of ethnic communities and the personal relations of Immigrants. American Journal of Sociology, 70(2), 193-205.

Brunsson, N. (2006). The organization of hypocrisy: Talk, decisions and actions in organizations (2nd ed.). Business Schoo Press.

Bührmann, A. D., \& Schönwälder, K. (2017). Public organisations and diversity: Approaches to an under-researched topic. Journal of Ethnic and Migration Studies, 43(10), 1635-1643.

Caglar, A. (2006). Hometown associations, the rescaling of state spatiality and migrant grassroots transnationalism. Global Networks, 6(1), 1-22.

Caponio, T. (2005). Policy networks and immigrants' associations in Italy: The cases of Milan, Bologna and Naples. Journal of Ethnic and Migration Studies, 31(5), 931-950.

Castells, M. (1996). The rise of network society. Blackwell.

Castles, S., Haas, H. de, \& Miller, M. J. (2013). The age of migration: International population movements in the modern world. Palgrave Macmillan.

Cohen, M. D., March, J. G., \& Olsen, J. P. (1972). A Garbage can model of organizational choice. Administrative Science Quarterly, 17(1), 1-25.

Cranston, S., Schapendonk, J., \& Spaan, E. (2018). New directions in exploring the migration industries: Introduction to special issue. Journal of Ethnic and Migration Studies, 44(4), 543-557.

Cuttitta, P. (2018). Repoliticization through search and rescue? Humanitarian NGOs and migration management in the Central Mediterranean. Geopolitics, 23(3), 632-660.

Czarniawska, B., \& Hernes, T. (Eds.). (2005). Actor-network theory and organizing. Liber.

Dahinden, J. (2016). A plea for the 'de-migranticization' of research on migration and integration. Ethnic and Racial Studies, 39(13), 2207-2225

Dahlvik, J. (2018). Inside asylum bureaucracy: Organizing refugee status determination in Austria. Springer.

Debonneville, J. (2021). An organizational approach to the Philippine migration industry: Recruiting, matching and tailoring migrant domestic workers. Comparative Migration Studies, 9(1), 12. https://doi.org/10.1186/ s40878-020-00220-2

Deephouse, D. L., \& Suchman, M. (2008). Legitimacy in organizational institutionalism. In R. Greenwood, C. Oliver, R. Suddaby, \& K. Sahlin (Eds.), The SAGE handbook of organizational institutionalism (pp. 49-77). SAGE.

DiMaggio, P. J., \& Powell, W. W. (1983). The Iron Cage Revisited: Institutional isomorphism and collective rationality in organizational fields. American Sociological Review, 48(2), 147-160.

Elrick, J. (2016). Screening, skills and cultural fit: Theorizing immigrant skill utilization from an organizational perspective. Journal of International Migration and Integration, 17(3), 801-817.

Emirbayer, M., \& Johnson, V. (2008). Bourdieu and organizational analysis. Theory and Society, 37(1), 1-44.

Eule, T. G. (2016). Inside immigration law: Migration management and policy application in Germany. Routledge.

Faist, T. (2010). The crucial meso-level. In M. Martiniello \& J. Rath (Eds.), Selected studies in international migration and immigrant incorporation (pp. 59-90). Amsterdam University Press. 
Fauser, M. (2012). Migrants and cities: The accommodation of migrant organizations in Europe. Ashgate.

Favell, A. (2010). Integration and nations: The nation-state and research on immigrants in Western Europe. In M. Martiniello \& J. Rath (Eds.), Selected studies in international migration and immigrant incorporation (pp. 371-404). Amsterdam University Press.

Favell, A. (2019). Integration: Twelve propositions after Schinkel. Comparative Migration Studies, 7(1), 21. https://doi.org/10. 1186/s40878-019-0125-7

Findlay, A., McCollum, D., Shubin, S., Apsite, E., \& Krisjane, Z. (2013). The role of recruitment agencies in imagining and producing the 'good' migrant. Social and Cultural Geography, 14(2), 145-167.

Fligstein, N., \& McAdam, D. (2012). A theory of fields. Oxford University Press.

Gammeltoft-Hansen, T., \& Sørensen, N. N. (Eds.). (2013). The migration industry and the commercialization of international migration. Routledge.

Geiger, M., \& Pécoud, A. (2014). International organisations and the politics of migration. Journal of Ethnic and Migration Studies, 40(6), 865-887.

Georgi, F. (2010). For the benefit of some: The international organization for migration and its global migration management. In M. Geiger \& A. Pécoud (Eds.), The politics of international migration management (pp. 45-72). Palgrave Macmillan.

Gnes, D. (2016). Organisational legitimacy beyond ethnicity? Shifting organisational logics in the struggle for immigrant rights in Los Angeles. Journal of Ethnic and Migration Studies, 42(9), 1420-1438.

Gomolla, M., \& Radtke, F.-O. (2009). Institutionelle Diskriminierung: Die Herstellung ethnischer Differenz in der Schule (3rd ed.). VS Verlag.

Gutiérrez-Rodríguez, E. (2016). Sensing dispossession: Women and gender studies between institutional racism and migration control policies in the neoliberal university. Women's Studies International Forum, 54, 167-177.

Halm, D., \& Sezgin, Z. (2013). Introduction: Interplay between migrant organizations and their environment-Conceptual and theoretical framework. In D. Halm \& Z. Sezgin (Eds.), Migration and organized civil society: Rethinking national policy (pp. 1-21). Routledge.

Hantscher, S. (2019). The UNHCR and disaster displacement in the 21st century: An organizational analysis. Springer.

Harms-Dalibon, L. (2017). Surveillance and prayer-Comparing Muslim prison chaplaincy in Germany's federal states. Comparative Migration Studies, 5(1), 8. https://doi.org/10.1186/s40878-017-0051-5

Hatch, M. J. (2018). Organization theory: Modern, symbolic, and postmodern perspectives (4th ed.). Oxford University Press.

Imdorf, C. (2010). Wie Ausbildungsbetriebe soziale Ungleichheit reproduzieren: Der Ausschluss von Migrantenjugendlichen bei der Lehrlingsselektion. In H.-H. Krüger, U. Rabe-Kleeberg, R.-T. Kramer, \& J. Budde (Eds.), Bildungsungleichheit revisited: Bildung und soziale Ungleichheit vom Kindergarten bis zur Hochschule (pp. 259-274). VS Verlag.

Ireland, P. R. (1994). The policy challenge of ethnic diversity: immigrant politics in France and Switzerland. Harvard University Press.

Karakayali, J., \& zur Nieden, B. (2013). Rassismus und Klassen-Raum. Segregation nach Herkunft an Berliner Grundschulen. sublurban. Zeitschrift für kritische stadtforschung, 1(2), 61-78.

Lamba-Nieves, D. (2018). Hometown associations and the micropolitics of transnational community development. Journal of Ethnic and Migration Studies, 44(5), 754-772.

Lang, C. (2019). Die Produktion von Diversität in städtischen Verwaltungen. Wandel und Beharrung von Organisationen in der Migrationsgesellschaft. Springer.

Lang, C. (2020). Workforce diversity policies in practice: Drivers and barriers in local administrations. Ethnic and Racial Studies, 43(11), 1961-1980.

Lang, C. (2021). Accessing the public workforce: Organisational recruitment practices and the inclusion or exclusion of individuals of immigrant origin. Comparative Migration Studies, 9(1), 26. https://doi.org/10.1186/ s40878-021-00233-5

Leung, M., Waters, J. L. \& Ki, Y. (forthcoming). Schools as spaces for in/exclusion: young Mainland Chinese students and families in Hong Kong. Comparative Migration Studies.

Levitt, P. (2004). Redefining the boundaries of belonging: The institutional character of transnational religious life. Sociology of Religion, 65(1), 1-18.

Lindquist, J., Xiang, B., \& Yeoh, B. S. A. (2012). Opening the black box of migration: Brokers, the organization of transnational mobility and the changing political economy in Asia. Pacific Affairs, 85(1), 7-19.

Lipsky, M. (1980). Street-level bureaucracy. Russell Sage Foundation.

Liu-Farrer, G., \& Tran, A. H. (2019). Bridging the Institutional Gaps: International Education as a Migration Industry. International Migration, 57(3), 235-249.

Luhmann, N. (2018). Organization and decision. Cambridge University Press.

Maletzky de García, M. (2021). Bridging the state and market logics of refugee labour market inclusion—A comparative study on the inclusion activities of German professional chambers. Comparative Migration Studies, 9(1), 25. https:// doi.org/10.1186/s40878-021-00232-6

March, J. G. (1990). Decisions and organizations (Repr). Blackwell.

March, J. G., \& Simon, H. A. (1993). Organizations (2nd ed). Blackwell.

Martin, J. (2001). Organizational culture: Mapping the terrain. SAGE Publications.

Meyer, J. W., \& Rowan, B. (1977). Institutionalized organizations: Formal structure as myth and ceremony. American Journal of Sociology, 83(2), 340-363.

Meziani-Remichi, Y., \& Maussen, M. (2017). Recruitment in public administrations: Diversity policies and selection practices in a French city. Journal of Ethnic and Migration Studies, 43(10), 1679-1695.

Michalowski, I. (2015). What is at stake when Muslims join the ranks? An international comparison of military chaplaincy. Religion, State and Society, 43(1), 41-58.

Midtbøen, A. H. (2014). Discrimination of the second generation: Evidence from a field experiment in Norway. Journal of International Migration and Integration, 17(1), 253-272.

Nicholls, W., \& Uitermark, J. (2013). Post-multicultural cities: A comparison of minority politics in Amsterdam and Los Angeles, 1970-2010. Journal of Ethnic and Migration Studies, 39(10), 1555-1575. 
Oliver, C. (1991). Strategic responses to institutional processes. The Academy of Management Review, 16(1), 145-179. Osanami Törngren, S., \& Shinozaki, K. (2021). Challenging the binary: Reflections on multiple and unconventional positionality through a lens of multi-layered institutional whiteness. In D. Dandekar \& S. Martin (Eds.), Global South Scholars in the Western Academy. Routledge.

Østergaard-Nielsen, E. (2003). The politics of migrants'transnational political practices. International Migration Review, $37(3), 760-786$.

Pécoud, A. (2018). What do we know about the International Organization for Migration? Journal of Ethnic and Migration Studies, 44(10), 1621-1638.

Perkowski, N. (2019). 'There Are Voices in Every Direction': Organizational Decoupling in Frontex. JCMS: Journal of Common Market Studies, 57(5), 1182-1199.

Perna, R. (2021). Street-level workers, managers and institutional tensions: A comparative ethnography of healthcare practices of in/exclusion in three Italian public organisations. Comparative Migration Studies, 9(1), 16. https://doi. org/10.1186/s40878-021-00224-6

Però, D. (2008). Migrants and the politics of governance. The Case of Barcelona. Social Anthropology, 15(3), 271-286.

Pilati, K., \& Morales, L. (2016). Ethnic and immigrant politics vs. mainstream politics: The role of ethnic organizations in shaping the political participation of immigrant-origin individuals in Europe. Ethnic and Racial Studies, 39(15), 2796-2817.

Portes, A., Escobar, C., \& Arana, R. (2008). Bridging the gap: Transnational and ethnic organizations in the political incorporation of immigrants in the United States. Ethnic and Racial Studies, 31 (6), 1056-1090.

Pries, L. (Ed.). (2008). Rethinking transnationalism: The meso-link of organisations. Routledge.

Pries, L. (2010). (Grenzüberschreitende) Migrantenorganisationen als Gegenstand der sozialwissenschaftlichen Forschung: Klassische Problemstellungen und neuere Forschungsbefunde. In L. Pries (Ed.), Jenseits von, Identität oder Integration' (pp. 15-60). VS Verlag.

Pries, L., \& Sezgin, Z. (2012). Migration, Organizations and Transnational Ties. In L. Pries \& Z. Sezgin (Eds.), Cross border migrant organizations in comparative perspective (pp. 1-36). Palgrave Macmillan.

Ray, V. (2019). A theory of racialized organizations. American Sociological Review, 84(1), 26-53.

Reitter, V. (forthcoming). Statelessness in Austria and Spain: Displacing narratives of vulnerability. In Jahrbuch Migrationsforschung: Vol. 6. Migrationsforschung und Migrationsgesellschaft: Aktuelle Herausforderungen und neue Perspektiven. Austrian Academy of Sciences Press.

Rodriguez, R. M. (2010). Migrants for export: How the Philippine State Brokers Labor to the World. University of Minnesota Press.

Rosenow-Williams, K. (2014). Organising Muslims and Integrating Islam: Applying Organisational Sociology to the Study of Islamic Organisations. Journal of Ethnic and Migration Studies, 40(5), 759-777.

Ruszczyk, S. P. (2018). Local governance of immigrant incorporation: How city-based organizational fields shape the cases of undocumented youth in New York City and Paris. Comparative Migration Studies, 6(1), 32. https://doi.org/10. 1186/s40878-018-0097-z

Salt, J., \& Stein, J. (1997). Migration as a business: The case of trafficking. International Migration, 35(4), 467-494.

Scheel, S., \& Ratfisch, P. (2014). Refugee protection meets migration management: UNHCR as a global police of populations. Journal of Ethnic and Migration Studies, 40(6), 924-941.

Scheffer, T. (2001). Asylgewährung: Eine ethnographische Analyse des deutschen Asylverfahrens. Lucius \& Lucius.

Schiller, M. (2016). European cities, municipal organizations and diversity: The new politics of difference. Palgrave Macmillan.

Schinkel, W. (2018). Against 'immigrant integration': For an end to neocolonial knowledge production. Comparative Migration Studies, 6(1), 31. https://doi.org/10.1186/s40878-018-0095-1

Schrover, M., \& Vermeulen, F. (2005). Immigrant organisations. Journal of Ethnic and Migration Studies, 31(5), 823-832.

Scott, W. R. (2008). Institutions and organizations: Ideas and interests (3rd ed.). Sage.

Scott, W. R., \& Davis, G. F. (2007). Organizations and organizing: Rational, natural, and open system perspectives (1st ed.). Pearson Prentice Hall.

Sezgin, Z. (2010). Türkische Migrantenorganisationen in Deutschland —Zwischen Mitgliederinteressen und institutioneller Umwelt. In L. Pries \& Z. Sezgin (Eds.), Jenseits von ,Identität oder Integration' (pp. 201-232). VS Verlag für Sozialwissenschaften.

Sykes, B., \& Kuyper, H. (2013). School segregation and the secondary-school achievements of youth in the Netherlands. Journal of Ethnic and Migration Studies, 39(10), 1699-1716.

Thompson, V. E., \& Zablotsky, V. (2016). Rethinking diversity in academic institutions. For a repoliticization of difference as a matter of social justice. Wagadu: A Journal of Transnational Women's and Gender Studies, (16), 77-95.

Tillie, J. (2004). Social capital of organisations and their members: Explaining the political integration of immigrants in Amsterdam. Journal of Ethnic and Migration Studies, 30(3), 529-541.

Tolbert, P. S., \& Hall, R. H. (2009). Organizations. Structures, processes, and outcomes. Pearson Prentice Hall.

Triandafyllidou, A. (2003). Immigration policy implementation in Italy: Organisational culture, identity processes and labour market control. Journal of Ethnic and Migration Studies, 29(2), 257-297.

Vermeulen, F. (2006). The immigrant organising process: Turkish organisations in Amsterdam and Berlin and Surinamese Organisations in Amsterdam, 1960-2000. Amsterdam University Press.

Vermeulen, F., \& Brünger, M. (2014). The Organisational Legitimacy of Immigrant Groups: Turks and Moroccans in Amsterdam. Journal of Ethnic and Migration Studies, 40(7), 979-1001.

Waldinger, R., \& Lichter, M. I. (2003). How the Other Half Works: Immigration and the Social Organization of Labor. University of California Press.

Walton-Roberts, M. (2021). Intermediaries and transnational regimes of skill: Nursing skills and competencies in the context of international migration. Journal of Ethnic and Migration Studies, 47(10), 2323-2340.

Weick, K. E. (1995). Sensemaking in organizations. SAGE.

Weiner, M. F. (2015). Whitening a diverse Dutch classroom: White cultural discourses in an Amsterdam primary school. Ethnic and Racial Studies, 38(2), 359-376.

Wooten, M. (2019). Race, organizations, and the organizing process. Emerald Group Publishing. 
Wooten, M., \& Hoffman, A. J. (2017). Organizational fields: Past, present and future. In R. Greenwood, C. Oliver, K. Sahlin, \& R. Suddaby (Eds.), The SAGE handbook of organizational institutionalism (pp. 55-74). SAGE.

Xiang, B. (2007). Global "Body Shopping": An Indian Labor System in the Information Technology Industry. Princeton University Press.

\section{Publisher's Note}

Springer Nature remains neutral with regard to jurisdictional claims in published maps and institutional affiliations.

Submit your manuscript to a SpringerOpen ${ }^{\circ}$ journal and benefit from:

- Convenient online submission

- Rigorous peer review

- Open access: articles freely available online

- High visibility within the field

Retaining the copyright to your article

Submit your next manuscript at $\boldsymbol{\nabla}$ springeropen.com 